\title{
Review
}

\section{Prevalence of cutaneous warts in patients with systemic lupus erythematosus: a systematic review}

\author{
Luísa Moreira Silva ${ }^{1}$, Willer Gonçalves Dourado Santos ${ }^{1}$, Mittermayer Barreto Santiago ${ }^{1,2}$ \\ ${ }^{1}$ Escola Bahiana de Medicina e Saúde Pública, Salvador, Bahia, Brazil \\ 2 Serviços Especializados em Reumatologia da Bahia, Salvador, Bahia, Brazil
}

\begin{abstract}
The aim of this study was to review and evaluate systematically the scientific evidence on the relationship between systemic lupus erythematosus (SLE) and cutaneous warts (CW) caused by human papillomavirus (HPV) infection. With strict inclusion and exclusion criteria, we extensively searched the PUBMED, BVS (Virtual Health Library), and SCOPUS databases for the studies that evaluated the prevalence of $\mathrm{CW}$ in patients with SLE. Secondary references were additionally obtained from the selected articles. Only four articles met the research criteria and showed a higher frequency of CW in SLE patients compared to healthy controls. One of them highlighted about rheumatoid factor (RF) in the sera of patients with SLE and found an inverse correlation between the occurrence of warts and RF autoantibody. Moreover, most of the selected articles showed that the presence of CW did not correlate with the use of immunosuppressive drugs. Therefore, these findings suggest that the prevalence of CW in patients with SLE is probably high due to the defects in immune mechanisms, independently of immunosuppressive drugs.
\end{abstract}

Key words: Cutaneous warts; Systemic lupus erythematosus; Immunosuppressive drugs; HPV; Human Papillomavirus.

J Infect Dev Ctries 2016; 10(9):902-906. doi:10.3855/jidc.7947

(Received 27 November 2015 - Accepted 25 April 2016)

Copyright (C) 2016 Silva et al. This is an open-access article distributed under the Creative Commons Attribution License, which permits unrestricted use, distribution, and reproduction in any medium, provided the original work is properly cited.

\section{Introduction}

Human papillomavirus (HPV) is a DNA virus of the Papillomaviridae family. It presents tropism for epithelial cells and can cause skin and/or mucous lesions [1]. Warts are the most common clinical manifestations of HPV infection. These lesions are arranged in the form of tumors that affect various locations, particularly the skin of the extremities, mucosa, genital skin, and oral and laryngeal mucosa [2]. Among them, cutaneous warts (CW) commonly affect the patients with immune disorders, such as systemic lupus erythematosus (SLE) - a prototype of autoimmune disease.

CW are caused by HPV types 1, 2, and 4 . Occasionally, other genomic types are also associated with immunosuppressed patients (e.g., HPV-75-77) presenting numerous and more recalcitrant injuries. There is high incidence of $\mathrm{CW}$ in general population, particularly in children, with an estimated prevalence rate of 33\% [3]. The lesions are often seen on the hands and predominantly on the fingers. Macroscopically, they appear as small papules with dome-shaped, keratotic, and warty surfaces.
HPV can spread through direct or indirect contact with the individual exhibiting an injury. The presence of the epithelial barrier dysfunction, which is caused by minor trauma, allows the penetration of the virus. After inoculation, the incubation period ranges from three weeks to eight months. The time frame and type of injury are directly related to the number of virus particles detected. Younger warts contain higher viral load compared to old warts [4]. Also, it is believed that in immunocompetent individuals, $\mathrm{CW}$ are harmless and can be eliminated by the body's natural immunity within months or years [5].

SLE is an autoimmune disorder characterized by multisystem inflammation, increased amount of circulating autoantibodies, and varied clinical manifestations [6]. Its pathogenesis is influenced by genetic and environmental factors. SLE patients have an increased susceptibility to infections, which has been considered as an important factor for triggering the autoimmune disease. Immunodeficiency disorders in patients with SLE increases the chances of HPV infection $[7,8]$. Some previous studies have shown the association between $\mathrm{CW}$ and immunosuppression $[9,10]$. Therefore, the main objective of the present 
study is to investigate the prevalence of $\mathrm{CW}$ in patients with SLE.

\section{Material And Methods}

We searched articles indexed in electronic databases BVS (Virtual Health Library), SCOPUS, and MEDLINE (National Library of Medicine, Bethesda, MD) between 1966 and 2015. According to the DeCS (Health Sciences Descriptors version December 17, 2013), the descriptors used for this study were: wart and lupus; human papillomavirus and lupus; cutaneous HPV and lupus, and their corresponding words in Portuguese and Spanish languages. In addition, secondary references from the selected articles were also searched to verify other potentially relevant studies. Review articles, case reports, and articles addressing only the treatment were excluded.

In order to evaluate the articles used in this research, we used the methodology employed by the Strengthening the Reporting of Observational Studies in Epidemiology (STROBE) Initiative, 2007. It consisted of a checklist of 22 items with recommendations about what should be included for an accurate and complete analysis of the observational studies, without any reference to the quality of the study [11]. We also used the strength of recommendation and level of evidence from diagnostic studies based on the research design, as mentioned in the Oxford Centre For Evidence-based Medicine (http://www.cebm.net/ocebm-levels-of-evidence/).

\section{Results}

A total of 78 studies were identified through computerized search. After analyzing the titles, articles were then selected by reading the abstracts and their texts. A total of four articles were included in this systematic review, with the number of patients ranging from 56 to 204 individuals. According to the STROBE checklist, the number of essential items identified in the studies ranged from 14 to 19 , with a median value of 16.2 (Table 1). The degree of recommendation of articles was B while the level of evidence corresponded to $3 \mathrm{~A}$. The four sample articles presented a score greater than $60 \%$ on the sum of items evaluated. The article by

Table 1. Analysis of the selected articles according to the STROBE criteria.

\begin{tabular}{|c|c|c|c|c|c|c|}
\hline \multicolumn{3}{|l|}{ ARTICLE } & \multirow[t]{2}{*}{ Yell \& Burge (8) } & \multirow[t]{2}{*}{$\begin{array}{c}\text { Korkmaz \& } \\
\ddot{U} \operatorname{rer}(9)\end{array}$} & \multirow[t]{2}{*}{$\begin{array}{c}\text { Johansson et al. } \\
\text { (10) }\end{array}$} & \multirow[t]{2}{*}{$\begin{array}{c}\text { Martínez- } \\
\text { Martínez et al. } \\
\text { (11) }\end{array}$} \\
\hline \multicolumn{3}{|l|}{ STROBE } & & & & \\
\hline Item & & $\mathbf{N}^{\mathbf{0}}$ & & & & \\
\hline Title and abstract & & 1 & $\mathrm{~N}$ & $\mathrm{Y}$ & $\mathrm{Y}$ & $\mathrm{Y}$ \\
\hline \multirow{2}{*}{ Introduction } & Background/ rationale & 2 & $\mathrm{~N}$ & $\mathrm{Y}$ & $\mathrm{Y}$ & $\mathrm{Y}$ \\
\hline & Objectives & 3 & $\mathrm{~N}$ & $\mathrm{Y}$ & $\mathrm{Y}$ & $\mathrm{Y}$ \\
\hline \multirow{9}{*}{ Methods } & Study design & 4 & $\mathrm{Y}$ & $\mathrm{Y}$ & $\mathrm{Y}$ & $\mathrm{Y}$ \\
\hline & Setting & 5 & $\mathrm{~N}$ & $\mathrm{Y}$ & $\mathrm{Y}$ & $\mathrm{Y}$ \\
\hline & Participants & 6 & $\mathrm{~N}$ & $\mathrm{Y}$ & $\mathrm{Y}$ & $\mathrm{Y}$ \\
\hline & Variables & 7 & $\mathrm{Y}$ & $\mathrm{Y}$ & $\mathrm{Y}$ & $\mathrm{Y}$ \\
\hline & $\begin{array}{l}\text { Data sources/ } \\
\text { measurement }\end{array}$ & 8 & $\mathrm{Y}$ & $\mathrm{Y}$ & $\mathrm{Y}$ & $\mathrm{Y}$ \\
\hline & Bias & 9 & $\mathrm{~N}$ & $\mathrm{~N}$ & $\mathrm{~N}$ & $\mathrm{~N}$ \\
\hline & Study size & 10 & $\mathrm{Y}$ & $\mathrm{N}$ & $\mathrm{N}$ & $\mathrm{N}$ \\
\hline & Quantitative variables & 11 & $\mathrm{Y}$ & $\mathrm{Y}$ & $\mathrm{Y}$ & $\mathrm{Y}$ \\
\hline & Statistical methods & 12 & $\mathrm{~N}$ & $\mathrm{Y}$ & $\mathrm{Y}$ & $\mathrm{Y}$ \\
\hline \multirow{5}{*}{ Results } & Participants & 13 & $\mathrm{Y}$ & $\mathrm{Y}$ & $\mathrm{Y}$ & $\mathrm{Y}$ \\
\hline & Descriptive data & 14 & $\mathrm{Y}$ & $\mathrm{Y}$ & $\mathrm{Y}$ & $\mathrm{Y}$ \\
\hline & Outcome data & 15 & $\mathrm{Y}$ & $\mathrm{Y}$ & $\mathrm{Y}$ & $\mathrm{Y}$ \\
\hline & Main results & 16 & $\mathrm{Y}$ & $\mathrm{Y}$ & $\mathrm{Y}$ & $\mathrm{Y}$ \\
\hline & Other analyses & 17 & $\mathrm{Y}$ & $\mathrm{Y}$ & $\mathrm{Y}$ & $\mathrm{Y}$ \\
\hline \multirow{4}{*}{ Discussion } & Key results & 18 & $\mathrm{Y}$ & $\mathrm{Y}$ & $\mathrm{Y}$ & $\mathrm{Y}$ \\
\hline & Limitations & 19 & $\mathrm{Y}$ & $\mathrm{N}$ & $\mathrm{Y}$ & $\mathrm{Y}$ \\
\hline & Interpretation & 20 & $\mathrm{Y}$ & $\mathrm{Y}$ & $\mathrm{Y}$ & $\mathrm{Y}$ \\
\hline & Generalizability & 21 & $\mathrm{Y}$ & $\mathrm{Y}$ & $\mathrm{Y}$ & $\mathrm{Y}$ \\
\hline Other information & Funding & 22 & $\mathrm{~N}$ & $\mathrm{Y}$ & $\mathrm{N}$ & $\mathrm{Y}$ \\
\hline TOTAL & & & 14 & 19 & 19 & 20 \\
\hline Level of evidence & & & $3 \mathrm{~A}$ & $3 \mathrm{~A}$ & $3 \mathrm{~A}$ & $3 \mathrm{~A}$ \\
\hline Degree of recomm & lation & & $\mathrm{B}$ & $\mathrm{B}$ & $\mathrm{B}$ & $\mathrm{B}$ \\
\hline
\end{tabular}

$\mathrm{Y}=$ Yes; $\mathrm{N}=$ No. 
Yell et al. [7] reached a score of $63.63 \%$ while the articles by Korkmaz et al. [8] and Johansson et al. [12] reached $86.36 \%$ and Martinez-Martinez et al. reached $90.9 \%$ [13].

Yell and Burge [7] evaluated 204 patients with lupus erythematosus (LE), which were subdivided into the following groups: SLE, subacute cutaneous lupus erythematosus (SCLE), generalized discoid lupus erythematosus (DLE), localized DLE, and possible LE. The control group consisted of 205 patients from a dermatology clinic while the SLE group consisted of 68 patients. From the entire study population, 24 patients $(11.8 \%)$ had CW. Twelve patients of the SLE group $(17.6 \%)$ and five patients of the control group $(2.4 \%)$ had $\mathrm{CW}$. The difference between the entire LE population and the control group, in terms of the number of patients presenting $\mathrm{CW}$, was significantly high $(\mathrm{p}<0.001)$. This study also identified a higher prevalence of $\mathrm{CW}$ in the patients aged $>45$ years in the LE group. In the LE patients with warts, the results revealed no significant difference between those who were on immunosuppressive treatment and those who were not $(\mathrm{p}>0.5)$.

Korkmaz and Ürer [8] evaluated 58 patients with LE (mainly systemic), 74 patients with rheumatoid arthritis (RA), and 105 healthy individuals as controls. $\mathrm{CW}$ occurred more significantly in patients with LE than in controls or RA patients ( $p<0.003$ and $p<0.04$, respectively), with a prevalence rate of $34 \%, 13 \%$, and $17.5 \%$, respectively. This study also identified a high prevalence of $\mathrm{CW}$ in patients aged $>45$ years in the three groups of patients. There was no significant relationship between the use of immunosuppressive drugs and the appearance of CW in either of the LE and RA groups.

Johansson et al. [12] studied 56 patients with definite or probable SLE and compared to a control group of 160 patients. The control group consisted of consecutive patients either attending the dermatology outpatient department or admitted to hospital for various cutaneous tests. Patients admitted because of warts were excluded from the study. The control group consisted of 30 men and 130 women aged 20 years or more (mean $37-5$ years).

$\mathrm{CW}$ occurred at a high frequency in patients with SLE $(p<0.001)$ with a total prevalence of $45 \%$ in the first group, whereas only $12 \%$ of control patients had warts. This difference was even greater in patients $\geq 45$ years. The use of drugs such as corticosteroids and antimalarials had no influence on the frequency of warts. This study measured the levels of wart-virus antibodies in serum samples by immunodiffusion and found that the antibodies were less frequent in the sera of the SLE than in control group. Furthermore, rheumatoid factor (RF) was also investigated in the sera of the SLE patients by latex agglutination test. It was found that $24 \%$ of patients with positive RF had warts compared to $58 \%$ of patients with negative $\mathrm{RF}$, suggesting the participation of RF in the resistance for warts.

Martınez-Martınez et al. [13] evaluated factors associated with CW in 120 SLE patients and 550

Table 2. Summary of the findings retrieved from the four articles included in the present review.

\begin{tabular}{|c|c|c|c|c|}
\hline Reference & Origin/ Year & Type of study & $\begin{array}{l}\text { Population and comparison } \\
\text { group }\end{array}$ & Results \\
\hline $\begin{array}{l}\text { Yell \& Burge } \\
\text { (8) }\end{array}$ & Ukraine/1993 & $\begin{array}{l}\text { Case series with } \\
\text { comparison group }\end{array}$ & $\begin{array}{l}204 \mathrm{LE}(158 \mathrm{~W}, 46 \mathrm{M}) \\
205 \mathrm{CG}\end{array}$ & $\begin{array}{l}17.6 \% \text { of SLE subgroup had CW } \\
\text { against } 2.4 \% \text { in the control group. }\end{array}$ \\
\hline $\begin{array}{l}\text { Korkmaz \& } \\
\text { Ürer (9) }\end{array}$ & Turkey/2003 & $\begin{array}{l}\text { Case series with } \\
\text { comparison groups }\end{array}$ & $\begin{array}{l}58 \mathrm{LE}(53 \mathrm{~W}, 5 \mathrm{M}) \\
74 \mathrm{RA}(63 \mathrm{~W}, 11 \mathrm{M}) \\
105 \mathrm{CG}(68 \mathrm{~W}, 37 \mathrm{M})\end{array}$ & $\begin{array}{l}34 \% \text { of LE group ( } 32 \% \text { of SLE } \\
\text { subgroup) had CW against } 17.5 \% \text { of } \\
\text { patients with RA and } 13 \% \text { of the } \\
\text { control group (P }<0.003) \text {. } \\
45 \% \text { of SLE group had CW against } \\
12 \% \text { of control group. }\end{array}$ \\
\hline $\begin{array}{l}\text { Johansson et } \\
\text { al. (10) }\end{array}$ & Finland/1977 & $\begin{array}{l}\text { Case series with } \\
\text { comparison group }\end{array}$ & $\begin{array}{l}56 \text { SLE or probable SLE } \\
(50 \mathrm{~W}, 6 \mathrm{M}) \\
160 \mathrm{CG}(130 \mathrm{~W}, 30 \mathrm{M})\end{array}$ & $\begin{array}{l}74 \% \text { of control patients had viral } \\
\text { antibodies against } 45 \% \text { of patients with } \\
\text { SLE. Among patients with SLE, } 24 \% \\
\text { of those who exhibited RF activity had } \\
\text { CW against } 58 \% \text { of those who had not } \\
\text { RF }(P<0.02) \text {. }\end{array}$ \\
\hline $\begin{array}{l}\text { Martinez- } \\
\text { Martinez et al. } \\
\text { (11) }\end{array}$ & Mexico/ 2013 & $\begin{array}{l}\text { Case series with } \\
\text { comparison group }\end{array}$ & $\begin{array}{l}120 \text { SLE }(114 \mathrm{~W}, 6 \mathrm{M}) \\
550 \text { RA }(488 \mathrm{~W}, 62 \mathrm{M})\end{array}$ & $\begin{array}{l}20 \% \text { of SLE patients had CW against a } \\
\text { lower percentage }(7.1 \%) \text { in patients } \\
\text { with RA. A significant relationship } \\
\text { between the presence of CW and the } \\
\text { use of MMF, antimalarial, and } \\
\text { glucocorticoids drugs in SLE patients } \\
\text { was found. }\end{array}$ \\
\hline
\end{tabular}


patients with RA. A total of $20 \%$ of the SLE patients had CW compared to $7.1 \%$ of patients in the RA group. They found a significant relationship between the presence of $\mathrm{CW}$ and the use of mycophenolate mofetil (MMF), an antimalarial drug, and glucocorticoids in SLE patients. It was found that $50 \%$ of the SLE patients were on MMF ( $p=0.012), 91.7 \%$ were on prednisone $(\mathrm{p}=0.052)$, and $66.7 \%$ were using antimalarial $(\mathrm{p}=$ $0.045)$ drugs.

The characteristics of the four sample studies included in this review are summarized in Table 2.

\section{Discussion}

Some of the previous studies have shown an increased prevalence of genital HPV infection in patients with SLE $[14,15]$. Similarly, the four selected articles for this review also showed a high prevalence of CW in SLE patients compared to the control group. This suggests that patients with SLE have an increased intrinsic risk of developing such infections that can be secondary to a primary abnormality in the patient's immune system. Interestingly, three out of four sample articles did not show any increased prevalence of $\mathrm{CW}$ in SLE patients under immunosuppressive therapy. This apparently controversial finding was also observed in the case of genital HPV in patients with SLE, whereas, in some studies, the use of immunosuppressive drugs was not associated with a high prevalence of HPV [16]. However, caution is necessary in the interpretation of these findings as, in a majority of the studies, "immunosuppressive use" has been analyzed as a qualitative variable and it does not necessarily mean in vivo immunosuppression.

Sulowicz et al. [17] found a prevalence of $38.5 \%$ of $\mathrm{CW}$ in a group of transplanted patients, which were more common in individuals aged above 45 years. Similarly, Blanes et al. [18] studied patients with HIV and reported a $\mathrm{CW}$ prevalence of $21.4 \%$ in a similar group of patients. These data suggest an association between the appearance of $\mathrm{CW}$ and immunosuppression.

To better understand the increased susceptibility of patients with SLE to viral infections, it is important to clarify the mechanisms involved in the immune response. T-lymphocytes are mainly classified into two large groups according to the types of cytokines they produce, i.e., Th1 and Th2. Th1 cells produce IL-2, INF- $\gamma$, and lymphotoxin for promoting cellular immunity against intracellular pathogens. The Th2 cells produce IL-4, IL-5, IL-6, and IL-10 for an effective response to helminths and allergic processes. SLE patients have predominantly $\mathrm{Th} 2$ response that results in the inefficiency of the immune mechanism in fighting against HPV infection.

Johansson et al. [12] observed an inverse correlation between the occurrence of $\mathrm{CW}$ and detection of RF in patients with SLE. They drew up the possibility that it could function as an immune protection tool against viral infections. A possible physiological role has been attributed to RF, such as removal of immune complexes, amplification of the IgG antibody response to the pathogenic agents, and increase in virus neutralization [19]. Thus, theoretically, it could optimize the body's resistance to the virus that causes warts in patients with SLE.

Although the number of articles included in the present review was small, all of them demonstrated a high prevalence of CW in SLE patients. A limitation in the selected articles was that the definition of the presence of CW was based only on clinical criteria and without any anatomo-pathological confirmation. It should also be noted that none of the studies in this review addressed the prevalence of the different serotypes of HPV in SLE patients exhibiting CW, which leaves room for the development of new studies in this area.

\section{Acknowledgements}

M.S. and W.G.D.S. are currently receiving a scholarship from Conselho Nacional de Desenvolvimento Científico e Tecnológico (CNPq). L.M.S. has a scholarship from FAPESB. The authors also wish to express their gratitude Dr. Hermila Guedes and Carla Baleeiro for their technical support.

\section{References}

1. Swygart C (1997) Human papillomavirus: disease and laboratory diagnosis. Br J Biomed Sci 54: 299-303.

2. Tschandl P, Rosendahl C, Kittler H (2014) Cutaneous human papillomavirus infection: manifestations and diagnosis. Curr Probl Dermatol 45: 92-97.

3. Cardoso J, Calonje E (2011) Cutaneous manifestations of human papillomaviruses: a review. Acta Dermatovenerol Alp Pannonica Adriat 20: 145-154.

4. Harwood CA, Surentheran T, McGregor JM, Spink PJ, Leigh IM, Breuer J, Proby CM (2000) Human papillomavirus infection and non-melanoma skin cancer in immunosuppressed and immunocompetent individuals. J Med Vir 61: 289-297.

5. Loo SK, Tang WY (2014) Warts (non-genital). BMJ Cli Evid Jun 12;2014. pii: 1710

6. Cojocaru M, Cojocaru IM, Silosi I, Vrabie CD (2011) Manifestations of systemic lupus erythematosus. Maedica 6: 330.

7. Yell J, Burge S (1993) Warts and lupus erythematosus. Lupus 2: 21-23.

8. Korkmaz C, Ürer SM (2004) Cutaneous warts in patients with lupus erythematosus. Rheumatol Int 24: 137-140. 
9. Piaserico S, Sandini E, Peserico A, Alaibac M (2014) Cutaneous viral infections in organ transplant patients. G Ital Dermatol Venereol 149: 409-415.

10. Reusser NM, Downing C, Guidry J, Tyring SK (2015) HPV Carcinomas in Immunocompromised Patients. J Clin Med 4: 260-281.

11. Malta M, Cardoso LO, Bastos FI, Magnanini MM, Silva CM (2010) STROBE initiative: guidelines on reporting observational studies. Rev Saude Publica 44: 559-565.

12. Johansson E, Pyrhönen S, Rostila T (1977) Warts and wart virus antibodies in patients with systemic lupus erythematosus. BMJ 1(6053): 74-76.

13. Martinez-Martinez MU, Baranda-Candido L, Abud-Mendoza C (2013) Cutaneous papillomavirus infection in patients with rheumatoid arthritis or systemic lupus erythematosus. A casecontrol study. Lupus 22: 948-952.

14. Tam LS, Chan AY, Chan PK, Chang AR, Li EK (2004) Increased prevalence of squamous intraepithelial lesions in systemic lupus erythematosus: association with human papillomavirus infection. Arthritis Rheum 50: 3619-3625.

15. Santana IU, Gomes AN, Lyrio LD, Rios Grassi MF, Santiago MB (2011) Systemic lupus erythematosus, human papillomavirus infection, cervical pre-malignant and malignant lesions: a systematic review. Clin Rheumatol 30: 665-672

16. Lyrio LD, Rios Grassi MF, Santana IU, Santiago MB (2013) Prevalence of cervical human papillomavirus infection in women with systemic lupus erythematosus. Rheumatol Int 33: 335-340.

17. Sulowicz J, Wojas-Pelc A, Kuzniewski M, Ignacak M, Janda K, Sulowicz W (2013) Cutaneous viral infections in patients after kidney transplantation: risk factors. Pol Arch Med Wewn 123: 686-692.

18. Blanes M, Belinchón I, Merino E, Portilla J, Sánchez-Payá J, Betlloch I (2010) Current prevalence and characteristics of dermatoses associated with human immunodeficiency virus infection. Actas Dermosifiliogr 101: 702-709.

19. Suslov K (2014) Neutralization-Enhancing RF Antibodies for HIV Vaccines. Front Immunol. 5: 634.

\section{Corresponding author}

Mittermayer B. Santiago

Serviços Especializados em Reumatologia da Bahia

Rua Conde Filho 117, Graça

Salvador, Bahia

Brazil, CEP 40.150-150.

Phone: +55 71-30229886

Fax: +55 71- 30145663

Email: mitter.santiago@serdabahia.com.br

Conflict of interests: No conflict of interests is declared. 